\title{
Impact of Relationship Marketing Orientation on Customer Loyalty of Select Banks in the District of Burdwan, West Bengal
}

Dr. Pradipta Gangopadhyay, Joint Director, Institute of Cost Accountants of India, Kolkata, Secretary - Banking \& Insurance Committee, ganguly.pradipta@gmail.com

Dr. Solai Bhaskaran, Professor, Acharya Bangalore B-School, Bengaluru

\begin{abstract}
In today's competitive world,customers are in the center of the banking companies' attention and their satisfaction is the main factor in gaining competitive advantage. The fundamental prerequisite for achieving customers' satisfaction is to fully meet or exceed their needs, wants, desires, expectations, and their willingness to purchase products/services. Customer loyalty emerges as one of the most important challenges faced by bank marketers. Cultivating loyal customers is frequently argued to be the single mostimportant driver of organizations' longterm financial performance and customer base, which can lead to increased sales and customer share, lower costs, and higher prices on services. The purpose of this study is to empirically investigate the impact of relationship marketing orientation on customer loyalty in select banks in the district of Burdwan, West Bengal. The findings contribute to understanding the relationships between different dimensions of relationship marketing orientation, customer loyalty and demographic variables; provide critical implications for bank managers; and highlight directions for future research.
\end{abstract}

Keywords: Relationship Marketing, Customer loyalty, Trust, Commitment

\section{Introduction}

The marketplace today is very dynamic, vibrant and competitive. The customers are smarter, more informed, and have an access to many channels and choices which they take little time to exercise.
Customer can easily defect to competitors who promise better offerings at lower prices (Bhardwaj, 2007). It is this environment that forces different organizations to adopt innovative marketing strategies-the most common being Relationship Marketing Strategy (RMS) which "strives to get the firm close to the customers in order to enable it to accurately and adequately discern and satisfy their needs" (Ndubisi et al, 2005). A successful 'firmcustomer relationship' enables the firm to gather exclusive information about the customers' needs and wants which is useful not only in serving the customers better but it also helps firms to achieve a competitive edge over its peers and rivals.

The environment of the banking business in India has undergone a sea change over the last three decades with the liberalization policies of the successive governments. The complex and competitive environment has resulted in a shift of the customers' attitude as they have become highly demanding in respect of the banking products and services and switching their loyalty according to their own sweet will. The high customer turnover today is attributed to the fact that they have wider choice and easy access to multiple options owing largely to the technological revolution. Hence it has become necessary to devise comprehensive and all-inclusive marketing strategies from 'reaching out to retaining' of customers with a special focus on the latter, which is discernible in their various marketing endeavours.

The banks which have predominantly promoted the transactional trait of its operation, of late are focusing 
on the relational aspect of marketing as is evident in their promotional efforts. Some of the taglines representing their brands are:

$\begin{array}{ll}\text { Name of the Bank } & \text { Campaign taglines } \\ \text { Allahabad Bank } & \text { - A tradition of trust } \\ \text { Bank of Baroda } & \text { - India's International Bank } \\ \text { Bank of India } & \text { - Relationship beyond banking }\end{array}$

To understand Relationship Marketing further especially in the banking branches of Kolkata the researcher has tried to delve deeper into the subject through a thorough literature review and propose a conceptual model involving relationship drivers affecting Relationship Marketing Strategy. Scholars and academicians have listed and theorized key relationship drivers/constructs/variableslike trust (Moorman et al., 1993; Morgan and Hunt, 1994; Ndubisi, 2004), Commitment (Moorman et al., 1993; Morgan and Hunt, 1994; Ndubisi, 2004), satisfaction (Sheith et al., 1988), Conflict Handling (Dwyer et al., 1987), empathy (Ndubisi, 2004)and many others through various marketing literatures.

The variables chosen for the current study are Trust and Commitment based on the following facts:

(i) The variables find a mention in the promotional efforts of the banks as referred to earlier.

(ii) The mid level bank officials whom the researcher interviewed and who act as a link between the rank \& file supplying ground level information to the policy makers stressed on the afore mentioned traits.

(iii) The customers spoken to by the researcher also corroborated the fact that they give importance to the variables chosen by the researcher.

In the current study the influence of each of the aforesaid independent variable (Trust and Commitment) on the dependent variable i.e.,Customer Loyalty $(\mathrm{CL})$ will be empirically tested. In other words the conceptual framework of the following figure will be empirically tested.
Figure1:Conceptual Framework

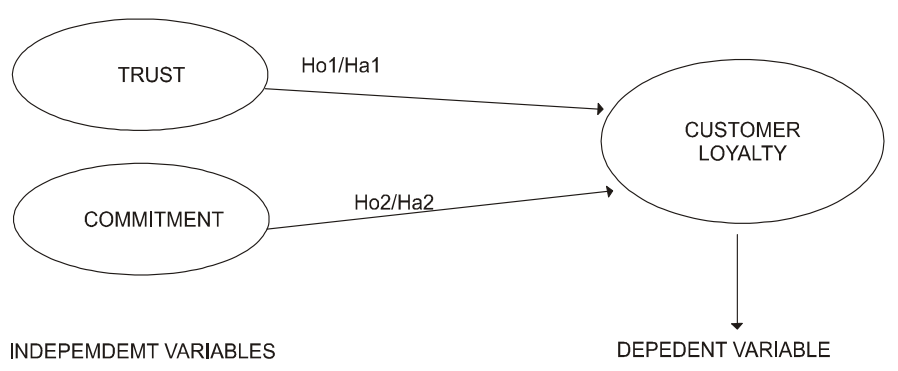

Before deliberating on this issue it is necessary to have some idea about the concept of trust and commitment. Trust was defined in 'The Journal of Marketing Research' by Christine Moorman et al(1992) as "the willingness to rely on an exchange partner in whom one has confidence".Gronroos (1990) emphasized that the resources of the seller personnel, technology and systems - have to be used in such a manner that the customer's trust in the resources involved and, thus, in the firm itself is maintained and strengthened.

Commitment is an important determinant of the strength of a marketing relationship. Commitment, according to Morgan \& Hunt, 1994, plays a central role in the relationship marketing paradigm. In marketing literature Moorman et al., 1992 have defined commitment as "an enduring desire to maintain a valued relationship". Thus commitment is enduring and implies a positive evaluation of a longterm relationship (Bowen \& Shoemaker, 1998; Moorman et al, 1992; Morgan \& Hunt, 1994). Consequently, Commitment is often seen as a key to long-term customer retention (Amine, 1998). This further implies a higher level of obligation to make a relationship succeed and to make it mutually satisfying and beneficial (Gundlach et al., 1995; Morgan and Hunt, 1994). Since, commitment is higher among individuals who believe that they receive more value from a relationship, highly committed customers should be willing to reciprocate effort on behalf of a firm due to past benefits received (Mowday et al., 1982) and highly committed firms will continue to enjoy the benefits of such reciprocity. 


\section{Objective of the study}

The objective of this study is to investigate the influence of selected independent variables (trust, commitment) on the dependent variable (customer loyalty) of the selected banking branches in the district of Burdwan in West Bengal.

\section{Research Hypotheses}

To give effect to the problem statement a number of null hypotheses have been formulated, stating that no relationship exists, as depicted in the conceptual diagram figure. Alternative hypotheses have been formulated stating that relationship exists, as depicted in conceptual diagram.

Specifically the null and alternative hypotheses are:

Ho1:There is no relationship between perceived Trust and Customer Loyalty in the selected banking branches in Burdwan.

Ha1:There exists a relationship between perceived Trust and Customer Loyalty in selected banking branches in Burdwan.

Ho2:There is no relationship between perceived Commitment and Customer Loyalty in selected banking branches inBurdwan.

$\mathrm{Ha} 2$ :There exists a relationship between perceived Commitment and Customer Loyalty in selected banking branches in Burdwan.

\section{Research Methodology}

A structured questionnaire was developed including some selected items from previous studies. In addition interviews were conducted with officers of the banks selected for the study in order to identify important aspects of Relationship Marketing to assist development of questionnaire items.

The questionnaire has two components- Part $A$ and Part B.

The first part (i.e., Part A) contains five items to gather some relevant demographical information about the respondents viz., gender, age, qualification, annual income, and number of years of association with the bank.
The second part (i.e., part B) contains 15 items to gather the responses (i.e., the perceptions) of respondents on a five point scale (the response alternatives being, strongly disagree/disagree/ neither agree nor disagree/agree/strongly agree) with respect to three aspects viz., trust [6 sub-variables viz., Security of Transaction, Reliable Promise, Consistent Service, Respect of Customers, Fulfills Obligation, Confidence in Service], commitment [4 sub-variables viz. Flexibility1, Adjustment, Flexibility2 and Personalised Services] and Customer Loyalty aspects [5 sub-variables viz. Satisfaction, Relationship Benefits, Cooperation, Bond, Experience].

The primary data collected have been intelligently collated, analysed and tabulated using appropriate statistical techniques with the help of a statistical software package, viz.,SPSS (version 20).

\section{Data Sources}

The researcher has chosen the public sector banks designated as scheduled commercial banks headquartered at Kolkata viz. UCO Bank, United bank of India and Allahabad Bank. The reason being:

(i) The study is based on banks in with branches in Burdwan district of West Bengal.

(ii) It helped the researcher design the questionnaire after talking to the officials who are involved in devising marketing strategies and policies.

(iii) It is basically a perception study. Hence it was essential to identify the customers interacting frequently with the bank. Speaking with the aforementioned officials helped the researcher to identify such customers.

There are 351 branches of UCO (79), UBI (North+South=118) and Allahabad (154) Bank in Burdwan and Kolkata. 35 branches were chosen (representing $10 \%$ of the number of branches) from among the 351 branches in the following manner.The branches were selected based on the premise of Convenience Sampling.

UCO Bank

- 8 branches

United Bank of India - $\quad 12$ branches

Allahabad Bank _ 15 branches

Total _ 35 Branches 
The customers chosen are those having current accounts enjoying cash/credit accounts/facilities, who utilize the aforementioned accounts for financing their working capital requirement and the accounts are active and transactions are regular in nature.

Information relating to 5508 Cash/Credit account holders was collected. Out of them contact details [telephone numbers (landline and cellular), e-mail i/ ds] of 550 (i.e $10 \%$ of 5508) account holders could be gathered and contacted to. 384 respondents (i.e $70 \%$ of 550) actually responded out of which 312 (57\% of 550) completed questionnaires were selected.

\section{Tools for Data Analysis}

Crosstabs and Chi-square-The researcher performed the Chi Square test for independence of attributes between two categorical variables which uses cross classification table to examine the nature of relationship between the variables (independent, and dependent).

Factor Analysis-Factor analysis is a statistical tool used to group variables with similar characteristics together. It helps to reduce large number of variables to a smaller number of manageable variables. The reduced number of factors is utilized to explain the observed variance in the large number of variables.

Correlation and Regression-The word "correlation" is used to denote the degree of association between the variables. In the current research the statistical tool has been used to find out the relationship between the individual independent variables (Trust, Commitment) and the dependent variable (Customer Loyalty).

"Regression" is used to denote estimation or prediction of the average value of one variable for a specified value of other variable.

\section{Pilot Survey:}

The researcher conducted a pilot survey to verify the strength of the measuring instrument viz., the questionnaire. A total of 50 participants were chosen for the pilot test and reliability test was performed using Cronbach's Alpha.
Reliability of a measure is an established tool for testing both consistency and stability. Consistency indicates closeness of the items measuring a concept. Cronbach's Alpha is a reliability coefficient that indicates how well the items in a set are positively correlated to one another. The coefficient can range between 0 and 1 . Closer the value of item to 1 greater is its reliability/consistency. In the present (pilot) study the three Key Constructs Trust (6 items), Commitment ( 4 items) and Customer Loyalty ( 5 items) have coefficient scores of $0.835,0.792,0.748$ which indicates that the items within the Key Constructs are closely related, hence are consistent/reliable.

\section{Empirical Survey and its Findings}

The researcher then proceeded with the analysis of the data of the main survey. The Reliability test was performed using Cronbach's Alpha on the responses of the 312 customers. The coefficient scores of 0.754 , 0.720 and 0.722 respectively of the independent (Trust and Commitment) and dependent variable (Customer Loyalty) shows that the responses are consistent and reliable.

Crosstabulation and Chi Square test were then performed in two stages to find out whether and how the sub variables (referred to earlier) of independent variables (trust, and commitment) and the sub variables (referred to earlier) of dependent variable (customer loyalty) are related to each other. The null hypothesis being that, there is no statistically significant relationship between the sub variables of independent variables and the sub variables of dependent variable.

In the first instance the null hypothesis is that there is no relationship between the sub variables of the independent variable trust and the sub variables of the dependent variable relationship marketing strategyand the low $p$ values $(p<0.001)$ obtained gave the strength to reject the same. In other words we accept the alternative hypothesis that there is relationship between the sub variables of the independent variable and the sub variables of the dependent variable. 
In the second instance the null hypothesis is that there is no statistically significant relationship between the sub variables of the independent variable commitment and the sub variables of the dependent variable relationship marketing strategy and the low $p$ values $(p<0.001)$ obtained prove that the same can be rejected. In other words we accept the alternative hypothesis that there is relationship between sub variables of the independent variable and the sub variables of the dependent variable.

Factor Analysis was then performed in three stages to reduce the number of variables into a manageable limit.

The tables showing the results are given below.

TABLE 1: Factor Analysis - Trust

\begin{tabular}{|c|c|c|}
\hline \multicolumn{3}{|c|}{ KMO and Bartlett's Test } \\
\hline \multicolumn{2}{|c|}{$\begin{array}{l}\text { Kaiser-Meyer-Olkin Measure of } \\
\text { Sampling Adequacy. }\end{array}$} & .758 \\
\hline \multirow[t]{3}{*}{$\begin{array}{l}\text { Bartlett's Test of } \\
\text { Sphericity }\end{array}$} & $\begin{array}{l}\text { Approx. } \\
\text { Chi-Square }\end{array}$ & 422.756 \\
\hline & Df & 15 \\
\hline & $p$ value & $<0.001$ \\
\hline
\end{tabular}

Source: worked out by using the SPSS (version 20) using responses to questionnaire

The value of KMO measure of Sampling Adequacy as shown in the table above for the variable Trust is 0.758 which is acceptable; hence Factor Analysis is appropriate for this data.

The Bartlett's test of Sphericity tests the null hypothesis that original matrix is an identity matrix. The $p$-value for the variable Trust is low enough $(p<0.001)$ to reject the null hypothesis. In other words there are relationships between the variables.

\section{TABLE2: Total Variance explained:Trust}

\begin{tabular}{|c|c|c|c|c|c|c|}
\hline \multicolumn{7}{|c|}{ Total Variance Explained } \\
\hline \multirow{2}{*}{$\begin{array}{l}\text { Com } \\
\text { pon } \\
\text { ent }\end{array}$} & \multicolumn{3}{|c|}{ Initial Eigenvalues } & \multicolumn{3}{|c|}{$\begin{array}{l}\text { Extraction Sums of } \\
\text { Squared Loadings }\end{array}$} \\
\hline & Total & $\begin{array}{l}\% \text { of } \\
\text { Variance }\end{array}$ & $\begin{array}{l}\text { Cumula } \\
\text { tive } \%\end{array}$ & Total & $\begin{array}{l}\text { \% of } \\
\text { Variance }\end{array}$ & $\begin{array}{l}\text { Cumula } \\
\text { tive } \%\end{array}$ \\
\hline 1 & 2.71 & 45.285 & 45.285 & 2.717 & 45.285 & 45.285 \\
\hline
\end{tabular}

\begin{tabular}{|l|l|l|l|l|l|l|}
\hline 2 & .994 & 16.570 & 61.855 & & & \\
\hline 3 & .761 & 12.683 & 74.538 & & & \\
\hline 4 & .624 & 10.400 & 84.939 & & & \\
\hline 5 & .532 & 8.867 & 93.806 & & & \\
\hline 6 & .372 & 6.194 & 100.000 & & & \\
\hline
\end{tabular}

Extraction Method: Principal Component Analysis.

Source: worked out by using the SPSS (version 20)using responses to questionnaire

The above table shows the eigenvalues associated with each factor which represents the variance explained by that particular linear component. SPSS was used to extract factors having eigenvalues more than 1 which left us with one component having actual eigenvalue of 2.717 having variance explaining capacity of $45.285 \%$ which is satisfactory.

TABLE 3: Component Matrix:Trust

\begin{tabular}{|c|c|}
\hline \multicolumn{2}{|l|}{ Component Matrixa } \\
\hline & $\begin{array}{l}\text { Compo } \\
\text { nent } 1\end{array}$ \\
\hline $\begin{array}{l}\text { TRUST : SECURITY OF TRANSACTION:The } \\
\text { bank is very concerned with security for my } \\
\text { transaction }\end{array}$ & .769 \\
\hline $\begin{array}{l}\text { TRUST : RELIABLE PROMISE : The bank's } \\
\text { promises are reliable }\end{array}$ & .693 \\
\hline $\begin{array}{l}\text { TRUST : CONSISTENCY IN SERVICE : The } \\
\text { bank is consistent in providing quality } \\
\text { service }\end{array}$ & .500 \\
\hline $\begin{array}{l}\text { TRUST : RESPECT OF CUSTOMERS: The } \\
\text { employees of the bank show respect to } \\
\text { customers }\end{array}$ & .753 \\
\hline $\begin{array}{l}\text { TRUST : FULFILLS OBLIGATION : The bank } \\
\text { fulfils it's obligations to customers }\end{array}$ & .621 \\
\hline $\begin{array}{l}\text { TRUST : CONFIDENCE IN SERVICE : I have } \\
\text { confidence in the bank's services }\end{array}$ & .666 \\
\hline $\begin{array}{l}\text { Extraction Method : Principal Component } \\
\text { Analysis. }\end{array}$ & \\
\hline a. 1 components extracted. & \\
\hline
\end{tabular}

Source:worked out by using the SPSS (version 20)using responses to questionnaire

The Component matrix above shows factor loadings against component 1 extracted earlier. All the loadings are significant as the values are more than 
0.4. The order in which the customers considered the factors to be important is Security of transaction, Respect of customers, Reliable Promise, Confidence in service, Fulfills Obligation and Consistency in service.

\section{TABLE 4: Factor Analysis -Commitment}

\begin{tabular}{l|l|l|}
\hline \multicolumn{2}{|l|}{ KMO and Bartlett's Test } \\
\hline \multicolumn{2}{|l|}{$\begin{array}{l}\text { Kaiser-Meyer-Olkin Measure of Sampling } \\
\text { Adequacy. }\end{array}$} & .642 \\
\hline $\begin{array}{l}\text { Bartlett's } \\
\text { Test of }\end{array}$ & Approx. Chi-Square & 263.271 \\
\cline { 2 - 3 } Sphericity & Df & 6 \\
\cline { 2 - 3 } & p value & $<0.001$ \\
\hline
\end{tabular}

Source: worked out by using the SPSS (version 20)using responses to questionnaire

The value of KMO measure of Sampling Adequacy as shown in the table above for the variable Commitment is 0.642 which is acceptable; hence factor Analysis is appropriate for this data.

The Bartlett's test of Sphericity tests the null hypothesis that original matrix is an identity matrix. The $p$-value for the variable Commitment is highly significant $(p<0.001)$ and low enough to reject the null hypothesis. In other words there are relationships between the variables.

TABLE 5: Total variance explained : Commitment

\begin{tabular}{|l|l|l|l|l|l|l|}
\hline \multicolumn{3}{|l|}{ Total Variance Explained } \\
\hline $\begin{array}{l}\text { Com } \\
\text { pon } \\
\text { ent }\end{array}$ & \multicolumn{3}{|c|}{ Initial Eigenvalues } & \multicolumn{3}{|c|}{$\begin{array}{l}\text { Extraction Sums of } \\
\text { Squared Loadings }\end{array}$} \\
\cline { 2 - 7 } & Total & $\begin{array}{l}\text { \% of } \\
\text { Variance }\end{array}$ & $\begin{array}{l}\text { Cumula } \\
\text { tive \% }\end{array}$ & Total & $\begin{array}{l}\text { \% of } \\
\text { Variance }\end{array}$ & $\begin{array}{l}\text { Cumula } \\
\text { tive \% }\end{array}$ \\
\hline 1 & 2.717 & 45.285 & 45.285 & 2.717 & 45.285 & 45.285 \\
\hline 1 & 2.180 & 54.502 & 54.502 & 2.180 & 54.502 & 54.502 \\
\hline 2 & .793 & 19.815 & 74.317 & & & \\
\hline 3 & .644 & 16.110 & 90.427 & & & \\
\hline 4 & .383 & 9.573 & 100.000 & & & \\
\hline
\end{tabular}

Extraction Method: Principal Component Analysis.

Source: worked out by using the SPSS (version 20)using responses to questionnaire

The above table shows the eigenvalues associated with each factor which represents the variance explained by that particular linear component. SPSS was used to extract factors having eigenvalues more than 1 which left us with one component having actual eigenvalue of 2.180 having variance explaining capacity of $54.502 \%$ which is satisfactory.

TABLE 6: Component Matrix : Commitment

\begin{tabular}{|c|c|}
\hline \multicolumn{2}{|l|}{ Component Matrixa } \\
\hline & $\begin{array}{l}\text { Com } \\
\text { ponent } \\
1\end{array}$ \\
\hline $\begin{array}{l}\text { COMMITMENT : ADJUSTMENT : The bank } \\
\text { makes adjustments to suit my needs }\end{array}$ & .747 \\
\hline $\begin{array}{l}\text { COMMITMENT : PERSONALISED SERVICES : } \\
\text { The bank offers personalised services to } \\
\text { meet customers' needs }\end{array}$ & .698 \\
\hline $\begin{array}{l}\text { COMMITMENT : FLEXIBILITY1 : The bank is } \\
\text { flexible when its services are changed }\end{array}$ & .783 \\
\hline $\begin{array}{l}\text { COMMITMENT : FLEXIBILITY2 : The bank is } \\
\text { flexible in serving my needs }\end{array}$ & .722 \\
\hline $\begin{array}{l}\text { Extraction Method: Principal Component } \\
\text { Analysis. }\end{array}$ & \\
\hline
\end{tabular}

Source: worked out by using the SPSS (version 20)using responses to questionnaire

The Component matrix above shows factor loadings against component 1 extracted earlier. All the loadings are significant as the values are more than 0.4. The order in which the customers considered the factors to be important is Flexibility1, Adjustment, Flexibility2 and Personalised Services.

TABLE 7: Factor Analysis -Customer Loyalty

\begin{tabular}{|l|l|l|}
\hline \multicolumn{2}{|l|}{ KMO and Bartlett's Test } \\
\hline $\begin{array}{l}\text { Kaiser-Meyer-Olkin Measure of Sampling } \\
\text { Adequacy. }\end{array}$ & .773 \\
\hline Bartlett's & Approx. Chi-Square & 283.513 \\
\cline { 2 - 3 } $\begin{array}{l}\text { Test of } \\
\text { Sphericity }\end{array}$ & $\mathrm{Df}$ value & 10 \\
\cline { 2 - 3 } & $<0.001$ \\
\hline
\end{tabular}

Source: worked out by using the SPSS (version 20)based on responses to questionnaire

The value of KMO measure of Sampling Adequacy as shown in the table above for the variable Customer 
Loyalty is 0.773 which is good hence factor Analysis is appropriate for this data.

The Bartlett's test of Sphericity tests the null hypothesis that original matrix is an identity matrix. The $p$-value for the variable Customer Loyalty is highly significant $(p<0.001)$ and low enough to reject the null hypothesis. In other words there are relationships between the variables.

TABLE 8: Total variance explained : Customer Loyalty

\begin{tabular}{|l|l|l|l|l|l|l|}
\hline \multicolumn{7}{|l|}{ Total Variance Explained } \\
\hline $\begin{array}{l}\text { Com } \\
\text { pon } \\
\text { ent }\end{array}$ & \multicolumn{3}{|c|}{ Initial Eigenvalues } & \multicolumn{3}{|c|}{$\begin{array}{l}\text { Extraction Sums of } \\
\text { Squared Loadings }\end{array}$} \\
\cline { 2 - 7 } & Total & $\begin{array}{l}\text { \% of } \\
\text { Variance }\end{array}$ & $\begin{array}{l}\text { Cumula } \\
\text { tive } \%\end{array}$ & Total & $\begin{array}{l}\text { \% of } \\
\text { Variance }\end{array}$ & $\begin{array}{l}\text { Cumula } \\
\text { tive } \%\end{array}$ \\
\hline 1 & 2.393 & 47.869 & 47.869 & 2.393 & 47.869 & 47.869 \\
\hline 2 & .837 & 16.743 & 64.612 & & & \\
\hline 3 & .697 & 13.944 & 78.555 & & & \\
\hline 4 & .579 & 11.583 & 90.138 & & & \\
\hline 5 & .493 & 9.862 & 100.000 & & & \\
\hline Extraction Method: Principal Component Analysis. \\
\hline
\end{tabular}

Source: worked out by using the SPSS (version 20)based on responses to questionnaire

The above table shows the eigenvalues associated with each factor which represents the variance explained by that particular linear component. SPSS was used to extract factors having eigenvalues more than 1 which left us with one component having actual eigenvalue of 2.393 having variance explaining capacity of $47.869 \%$ which is satisfactory.

\section{TABLE 9: Component Matrix : Customer Loyalty}

\begin{tabular}{|c|c|}
\hline \multicolumn{2}{|l|}{ Component Matrixa } \\
\hline & $\begin{array}{l}\text { Comp } \\
\text { onent } \\
1\end{array}$ \\
\hline $\begin{array}{l}\text { Customer Loyalty : SATISFACTION:I am } \\
\text { satisfied with the overall relationship that } \\
\text { I have with my bank }\end{array}$ & .753 \\
\hline
\end{tabular}

Customer Loyalty : PLEASANT EXPERIENCE:I have had a pleasant experience of working with my bank .539

Customer Loyalty:RELATIONSHIP BENEFITS:

I receive benefits due to my relationship with bank

Customer Loyalty : BOND:I feel that I have a strong bond with my bank .680

Customer Loyalty : COOPERATION:I always receive cooperation from the bank due to my relationship with the bank .723

Extraction Method: Principal Component Analysis.

a. 1 components extracted.

Source: worked out by using the SPSS (version 20)based on responses to questionnaire

The Component matrix above shows factor loadings against component 1 extracted earlier. All the loadings are significant as the values are more than 0.4. The order in which the customers considered the factors to be important is Satisfaction, Relationship Benefits, Cooperation, Bond and Experience.

The table below represents the result of Correlations between independent variables and dependent variable. The outcome (correlation and $p$ value) reveals that the strength and significance of the relationship between individual Independent Variables (Trust, Commitment) and the Dependent Variable (Customer Loyalty). In other words the independent variables have a statistically significant relationship with the dependent variable individually as shown by the sig. value.

TABLE 10:Correlations between Independent and Dependent variables

\begin{tabular}{|l|l|l|}
\hline Correlations & & \\
\hline \multirow{3}{*}{ Trust } & & $\begin{array}{l}\text { Customer } \\
\text { Loyalty }\end{array}$ \\
\hline \multirow{2}{*}{ Commitment } & Pearson Correlation & 0.671 \\
\cline { 2 - 3 } & $\mathrm{p}$ value & $<0.001$ \\
\cline { 2 - 3 } & Pearson Correlation & 0.567 \\
\cline { 2 - 3 } & $\mathrm{p}$ value & $<0.001$ \\
\hline
\end{tabular}


Source: worked out by using the SPSS (version 20)based on responses to questionnaire

The researcher motivated by the above findings tried to find out the regression equation between the independent and the dependent variable. The result of the Regression analysis is given below.

Table 11 : Model Summary

\begin{tabular}{|l|l|l|l|l|}
\hline Model & $R$ & R Square & $\begin{array}{l}\text { Adjusted } \\
\text { R Square }\end{array}$ & $\begin{array}{l}\text { Std. Error of } \\
\text { the Estimate }\end{array}$ \\
\hline 1 & $0.680 a$ & 0.462 & 0.459 & 0.73584490 \\
\hline
\end{tabular}

a. Predictors: (Constant), Commitment, Trust

Source: worked out by using the SPSS (version 20)based on responses to questionnaire

In the first table R2, also called the Coefficient of Determination measures the proportion of total variation of the Dependent Variable (CL) explained by the Independent Variables (Trust, and Commitment). In the current research the Independent Variables explain $45.9 \%$ of the total variation of Dependent Variable which can be considered as satisfactory.

Table 12

\begin{tabular}{|l|l|l|l|l|l|l|}
\hline \multicolumn{2}{|l|}{ ANOVAa } & $\begin{array}{l}\text { Sum of } \\
\text { Squares }\end{array}$ & Df & $\begin{array}{l}\text { Mean } \\
\text { Square }\end{array}$ & F & Sig. \\
\hline 1 & $\begin{array}{l}\text { Regres } \\
\text { sion }\end{array}$ & 143.686 & 2 & 71.843 & 132.682 & $<0.001 b$ \\
\cline { 2 - 7 } & $\begin{array}{l}\text { Resi } \\
\text { dual }\end{array}$ & 167.314 & 309 & .541 & & \\
\cline { 2 - 7 } & Total & 311.000 & 311 & & & \\
\hline
\end{tabular}

a. Dependent Variable: Customer Loyalty

b. Predictors: (Constant), Commitment, Trust

Source: worked out by using the SPSS (version 20)based on responses to questionnaire

In this table the focus is on F-statistic. The tool tests the null hypothesis that none of the Independent Variables (Trust and Commitment) help explain the variation in Dependent Variable (RMS). The $p$ value $(p<0.001)$ indicates that the Fstatistic is large enough to reject the null hypothesis and accept the alternative hypothesis that the Independent Variables (Trust and Commitment) help explain the variation in Dependent Variable $(\mathrm{CL})$.

\section{Table 13}

\begin{tabular}{|c|c|c|c|c|c|c|}
\hline \multicolumn{7}{|c|}{ Coefficientsa } \\
\hline & & \multicolumn{2}{|c|}{$\begin{array}{l}\text { Unstandardized } \\
\text { Coefficients }\end{array}$} & \multicolumn{3}{|c|}{$\begin{array}{l}\text { Standardized } \\
\text { Coefficients }\end{array}$} \\
\hline \multicolumn{2}{|c|}{ Model } & B & Std. & Beta & $\mathrm{t}$ & Sig. \\
\hline 1 & $\begin{array}{l}\text { (Cons } \\
\operatorname{tant})\end{array}$ & $\begin{array}{l}-1.606 \mathrm{E} \\
-17\end{array}$ & .042 & & .000 & 1.000 \\
\hline & Trust & .554 & .062 & .554 & 8.987 & $<0.001$ \\
\hline & $\begin{array}{l}\text { Commi } \\
\text { ment }\end{array}$ & .159 & .062 & .159 & 2.588 & 0.010 \\
\hline
\end{tabular}

a. Dependent Variable: Relationship Marketing Strategy

Source: worked out by using the SPSS (version 20)based on responses to questionnaire

The aforementioned table helps us determine whether the Independent Variables (Trust and Commitment) together have a statistically significant relationship with the Dependent Variable $(\mathrm{CL})$ and the direction and strength of the relationship.

It is found that the Independent Variables trust and commitment are positively correlated with the Dependent Variable Customer Loyalty $(\mathrm{CL})$. The regression equation is as follows

\section{$\mathrm{CL}=-1.606 \mathrm{E}-017+0.554 \mathrm{TRUST}+0.159$ COMMITMENT}

Further the following Hypothesis were tested

Relationship between independent variables and dependent variable (CL)

Ho1: There is no relationship between perceived Trust and $C L$ in the selected banking branches in Burdwan district.

Ha1: There exists a relationship between perceived Trust and $\mathrm{CL}$ in selected banking branches in Burdwan district. 
In case of the relationship between Trust and Customer Loyalty the $p$ value $(p<0.001)$ indicates that the Hol is rejected. In other words alternative Hypothesis $\mathrm{Ha} 1$ that, there exists a relationship between perceived Trust and $\mathrm{CL}$ in selected banking branches in Burdwan district is accepted.

Ho2: There is no relationship between perceived Commitment and $\mathrm{CL}$ in selected banking branches in Burdwan district

Ha2: There exists a relationship between perceived Commitment and $\mathrm{CL}$ in selected banking branches in Burdwan district

In case of the relationship between Commitment and Customer Loyalty the $p$ value $(p<0.05)$ indicates that the Original Hypothesis Ho2 is rejected. In other words the Alternative Hypothesis ( $\mathrm{Ha} 2)$ that there is relationship between perceived Commitment and $\mathrm{CL}$ in selected banking branches in Burdwan district is accepted.

\section{Concluding Observations}

The analysis of the empirical research carried out on the responses of the customers of selected banking branches of UCO Bank, United Bank of India and Allahabad Bank has helped the researcher draw the following conclusions:

- The sub-factors of trust (i.e Security of Transaction, Reliable Promise, Consistent Service, Respect of Customers, Fulfills Obligation, Confidence in Service) have significant influence on the sub-factors of Customer Loyalty (i.e Satisfaction, Pleasant Experience, Relationship Benefits, Bond, Cooperation).

- The sub-factors of commitment (i.e Adjustment, Personalised services, Flexibility1, Flexibility2) have significant influence on the sub-factors of Customer Loyalty (i.e Satisfaction, Pleasant Experience, Relationship Benefits, Bond, Cooperation).

- The order of importance of the sub-factors of Trust, as per the customers of the selected banking branches of the Kolkata based banks are Security of Transaction, Respect of customers, Reliable promise, Confidence service, Fulfills obligation, Consistency in Service.

- The order of importance of the sub-factors of Commitment, as per the customers of the selected banking branches of the Kolkata based banks are Flexibility1, Adjustments, Flexibility2, Personalised Services.

- The order of importance of the sub-factors of Customer Loyalty, as per the customers of the selected banking branches of the Kolkata based banks are Satisfaction, Relationship Benefits, Cooperation, Bond, Pleasant experience.

- The independent variables (i.e trust, commitment,) have strong individual correlation with the dependent variable Customer Loyalty.

- The independent variables (i.e trust, commitment) individually help explain significant amount of variance of dependent variable, Customer Loyalty.

\section{Suggestions}

The researcher offers the following suggestions based on the empirical research carried out on the responses of the customers of selected banking branches of UCO Bank, United Bank of India and Allahabad Bank:

- Banks may concentrate more on trust while designing Relationship Marketing Strategies.

- Banks wishing to retain customers by developing trust may focus on factors like security of transaction, respect of customers, reliable promise, confidence, fulfills obligation, and consistency in service respectively.

- Banks wishing to retain customers by developing commitment may focus on flexibility, adjustment and personalized services respectively.

\section{References:}

1) Amine, A. (1998). Consumers' true brand loyalty: the central role of commitment. Journal of Strategic Marketing, 6(4), pp. 305-19. 
2) Bagozzi, Richard P. (1975). "Marketing as Exchange". Journal of Marketing, Volume 39, Issue 4 (October), 32-39.

3) Berry, Leonard L., (1980) ?Services Marketing is Different,?Business, Vol. 30(May-June), pp. 2429.

4) Berry, L. (1983) "Relationship Marketing" in Berry, Shostack, and Upah, G (eds), Emerging Perspectives on Services Marketing, American Marketing Association, Chicago, 1983.

5) Bhardwaj, Deepali (2007), Relationship Marketing in context to the IT industry VISION The journal of Business Perspective 11, (2), April June, 57-66

6) Bowen, J.T and Shoemaker, S (1998). Loyalty: a strategic commitment. The Cornell Hotel and Administration Quarterly, 44(5), pp. 31-47.

7) Dwyer, Robert, F., Paul, H. S, and Sejo, O. (1987), Developing buyer seller relationship, Journal of Marketing, 51 April, 11-27.

8) Grönroos, C. (1978), ?A Service Oriented Approach Marketing of Services, European Journal of Marketing, Vol. 12(8), pp 588-601.

9) Grönroos, C. (1982) "An applied service marketing theory", European Journal of Marketing, vol 16, 1982, pp 30-41.

10) Grönroos, C., "The Marketing Strategy Continuum: A Marketing Concept for the 1990s", ManagementDecision, Vol. 29 No. 1, 1991, pp. 7-13.

11) Grönroos, C. (1994), "From Marketing Mix to Relationship Marketing: Towards a Paradigm Shift in Marketing", Management Decision, Vol. 32 No. 2, pp. 4-20.

12) Gundlach, G.T., Achrol, R.S. and Mentzer, J.T. (1995), "The structure of commitment in exchange", Journal of Marketing, Vol. 59 No. 1, pp. 78-93.

13) Howard, J.A. and Sheth, J.N. (1969), The Theory of Buyer Behavior, Wiley, New York, NY.
14) Jackson, B.B. (1985) "Build customer relationships that last", Harvard Business Review, Nov-Dec, 1985.

15) Levitt, T. (1983) "After the sale is over", Harvard Business Review, Sept-Oct, 1983.

16) McGarry, Edmund D. (1951). "The Contactual Function in Marketing". The Journal of Business of the University of Chicago, Volume 24, Number 2 (April), 96-113.

17) McGarry, Edmund D. (1953). "Some new viewpoints in marketing". The Journal of Marketing, Volume 18, Issue 1 (July), 33-40.

18) Moorman, Christine, Deshpande, R. and Zaltman, G. (1992). 'Relationship betweenproviders and users of market research : the dynamics of trust within organisations'. Journal of Marketing Research, 29(3), pp. 314-28.

19) Moorman, C., Deshpande', R. and Zaltman, G. (1993), Relationship between Providers and Users ofMarket Research: The Role of Personal Trust, Marketing Science Institute, Cambridge,MA.

20) Morgan, R.M. and Hunt, S.D. (1994), "The commitment trust theory of relationship marketing", Journal ofMarketing, Vol. 58 No. 3, pp. 20-38.

21) Mowday, R., Porter, L. and Steers, R. (1982), "Organizational linkages: the psychology ofcommitment", Journal of Vocational Behavior, Vol. 14, pp. 224-47.

22) Ndubisi, N.O. (2004), "Understanding cultural dimensions on relationship marketing, its underpinnings and aftermath", Cross Cultural Management, Vol. 11 No. 3,pp. 70-89.

23) Schneider, B. (1980) "The service organization climate is critical", Organizational Dynamics, 1980.

24) Sheith, J. N., Gardner, D. and Garrett. D., (1988), Marketing Theory: Evolution and Evaluation, New York John Wiley, New York,54. 